\title{
Columbia River plume fronts. I. Hydrography, zooplankton distribution, and community composition
}

\author{
Cheryl A. Morgan ${ }^{1, *}$, Alex De Robertis ${ }^{2,4}{ }^{,}$Richard W. Zabel ${ }^{3}$ \\ ${ }^{1}$ Oregon State University, Hatfield Marine Science Center, Cooperative Institute for Marine Resources Studies, \\ 2030 S. Marine Science Drive, Newport, Oregon 97365, USA \\ ${ }^{2}$ NOAA Fisheries, Northwest Fisheries Science Center, Hatfield Marine Science Center, Newport, Oregon 97365, USA \\ ${ }^{3}$ NOAA Fisheries, Northwest Fisheries Science Center, 2725 Montlake Boulevard East, Seattle, Washington 98112-2097, USA \\ ${ }^{4}$ Present address: Alaska Fisheries Science Center, 7600 Sand Point Way NE, Seattle, Washington 98115, USA
}

\begin{abstract}
Well-defined fronts develop at the leading edge of the Columbia River (USA) plume. Convergent flow at these frontal boundaries may concentrate zooplanktonic organisms, which may in turn increase local prey availability to planktivorous fishes. In May 2001 and 2002, we compared the density, biomass and community structure of planktonic and neustonic zooplankton among plume fronts, low-salinity plume waters, and within the more saline, coastal marine waters. Fronts were characterized by distinct color discontinuities and high wave energy and were usually accompanied by foam and flotsam. The surface manifestation of the fronts was narrow and formed a thin lens of warm, low-salinity water overlying colder and more saline shelf waters. Overall, neither zooplankton nor neuston densities were higher in frontal regions. However, some zooplankton taxa were more abundant at fronts, and plankton biomass was 4 to 47 times higher in the frontal regions than in the neighboring plume and more oceanic shelf waters. The zooplankton community in the front habitat was distinct, particularly in the near-surface neuston, and was comprised of more surface-oriented organisms compared to the adjacent ocean and plume waters. We conclude that convergence zones at frontal regions at the leading edge of the Columbia River plume concentrate organisms that, either through active swimming or positive buoyancy, are maintained near the surface. Time scales of these fronts are much shorter than generation times in these organisms and therefore we believe that the observed changes in biomass and community composition in the front habitat are due to physical concentrating mechanisms and not to in situ growth. Increased zooplankton biomass at plume fronts may provide a unique and valuable food resource for planktivorous fishes, including juvenile salmonids as they transition from freshwater to the ocean environment.
\end{abstract}

KEY WORDS: Frontal regions · Zooplankton distribution · Community structure $\cdot$ Columbia River plume Resale or republication not permitted without written consent of the publisher

\section{INTRODUCTION}

River discharge into the coastal ocean creates thin buoyant lenses of fresher water over dense oceanic waters (Bowman \& Iverson 1978, Bowman 1988). When river outflow volume is sufficiently large in comparison to tidal volume, a clear frontal boundary is formed between the river plume and adjacent marine waters (Garvine \& Monk 1974). Convergent flows at these frontal boundaries have the potential to concentrate neustonic and planktonic organisms, including larval fishes (Le Févre 1986, Grimes \& Finucane 1991, Govoni \& Grimes 1992, Olson et al. 1994). Unlike many other oceanographic mechanisms that concentrate planktonic organisms, frontal boundaries are recurrent and spatially predictable, and thus may provide a predictable food source for plankton-feeding fishes.

Biological enrichment or concentration at a variety of oceanographic fronts has been observed in a wide range of organisms, including phytoplankton (Franks 1992, 
Uye et al. 1992, MacGregor \& Houde 1996), copepods (Mackas \& Louttit 1988, Russell et al. 1999), larval decapods (Zeldis \& Jillett 1982, Epifanio 1987, Eggleston et al. 1998) and larval fishes (Grimes \& Finucane 1991, Govoni \& Grimes 1992). Frontal zones have also been found to impact plankton community structure and composition (Grimes \& Finucane 1991, Shanks et al. 2000, 2002, 2003, Chiba et al. 2001, Munk et al. 2003).

The enhanced densities or biomass of organisms in frontal regions has been attributed to increased primary and secondary productivity (Uye et al. 1992) as well as physical concentrating mechanisms (Epifanio 1987, Govoni \& Grimes 1992). Franks (1992) demonstrated that surface-oriented organisms should become highly concentrated in frontal zones relative to nearby regions. His model predicts that concentration in convergence zones is expected for organisms that have some mechanism of maintaining their position at the surface, either from depth-directed swimming or due to positive buoyancy. However, in the absence of surface-directed behavior, concentration will not take place. Concentration in convergence zones could be beneficial to planktonic organisms by providing retention and landward transportation mechanisms for larval stages (Shanks \& Wright 1987, Eggleston et al. 1998). Increased plankton biomass could also provide regions of higher food availability for fishes such as juvenile salmon, and for birds that are surface-oriented visual predators.

The coastal ocean off of Oregon and Washington is heavily influenced by Columbia River freshwater discharge (Hickey \& Banas 2003). The Columbia River is the predominant river in the Pacific Northwest, supports the largest runs of Pacific salmon (Oncorhynchus spp.) in the continental United States, and carries the 6th largest volume of runoff in North America. Columbia River average annual runoff is second in the United states at approximately 244 billion $\mathrm{m}^{3}$ (Federal Columbia River Power System 2001; available at: http://www.bpa.gov/power/pg/ columbia_river_inside_story.pdf). This outflow results in a well-defined front at the leading edge of the brackish plume (Pearcy \& Keene 1974).

To test the hypothesis that plume fronts concentrate prey and are used as feeding habitats by juvenile salmon, we conducted a detailed physical and biological study of the fronts created at the leading edge of the Columbia River plume and the adjacent plume and oceanic waters in late May of
2001 and 2002 during the period of peak juvenile salmon entry into the coastal ocean. We contrasted the physical and biological characteristics of 3 habitats: (1) the front at the leading edge of the Columbia River plume; (2) adjacent locations in the higher-salinity, coastal shelf waters; and (3) the low-salinity plume (hereafter referred to as front, ocean and plume, respectively). We describe and compare the physical structure of these habitats, and test for differences among them in abundance, biomass, and community structure of plankton and neuston. In a companion paper (De Robertis et al. 2005, this volume), we describe the abundance and diet of juvenile salmon among these habitats.

\section{MATERIALS AND METHODS}

Field collection and physical data. We conducted hydrographic and plankton sampling of Columbia River plume frontal zones off the coasts of Oregon and Washington, USA, during daylight hours from the FV 'Frosti' on May 23 to 27, 2001 and May 23 to 29, 2002. Our sampling was designed to contrast the fronts with the adjacent habitats inside (plume) and outside

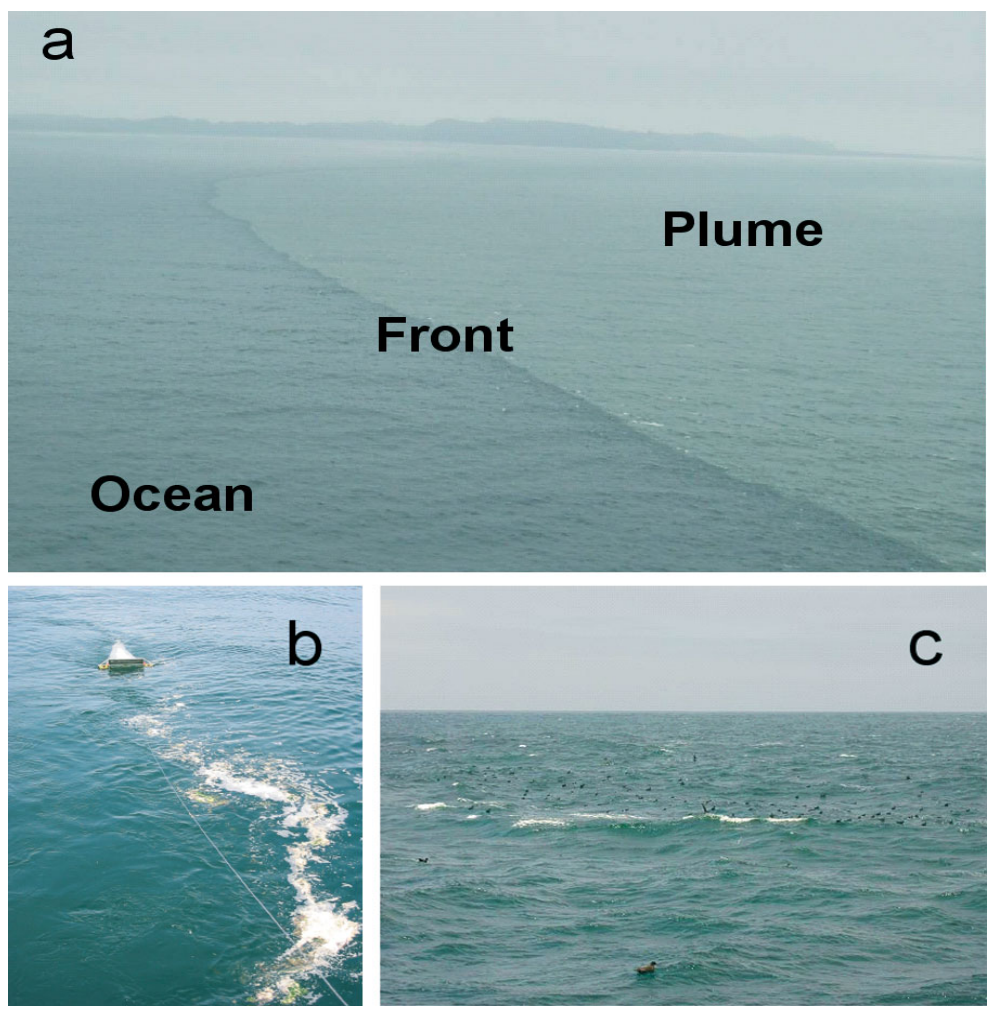

Fig. 1. (a) Front at leading edge of Columbia River plume, showing ocean, front and plume habitats (Photo courtesy of S. A. Hinton, NOAA Fisheries, Hammond, Oregon); (b) neuston-net fishing in front habitat; (c) bird aggregation at front habitat 


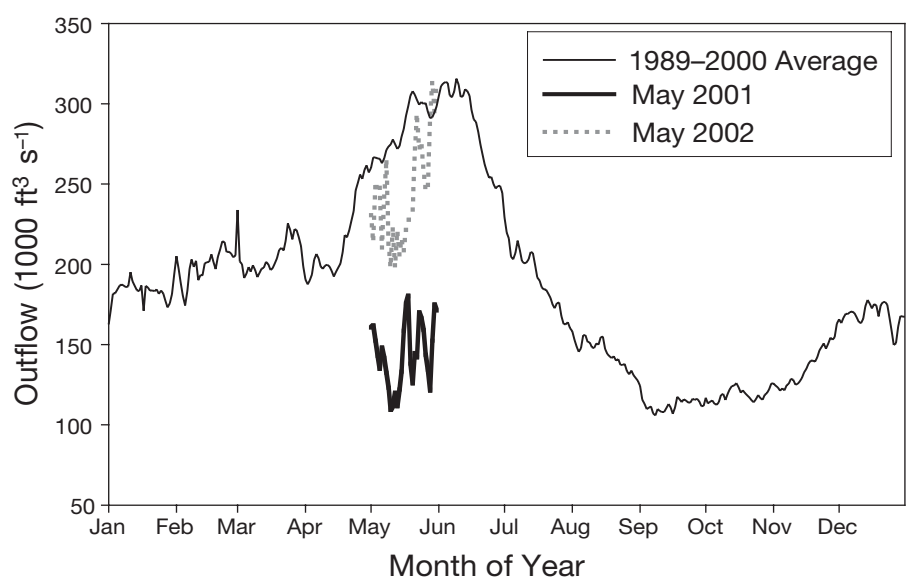

Fig. 2. Outflow at Bonneville dam (168 km upstream of river mouth) in thousands of $\mathrm{ft}^{3} \mathrm{~s}^{-1}\left(1000 \mathrm{ft}^{3}=28.3 \mathrm{~m}^{3}\right)$ showing $10 \mathrm{yr}$ average, and May 2001 and 2002. Data from the U.S. Army Corps of Engineers, Water Management Division (details at: www.nwd-wc.usace.army.mil/report.htm)
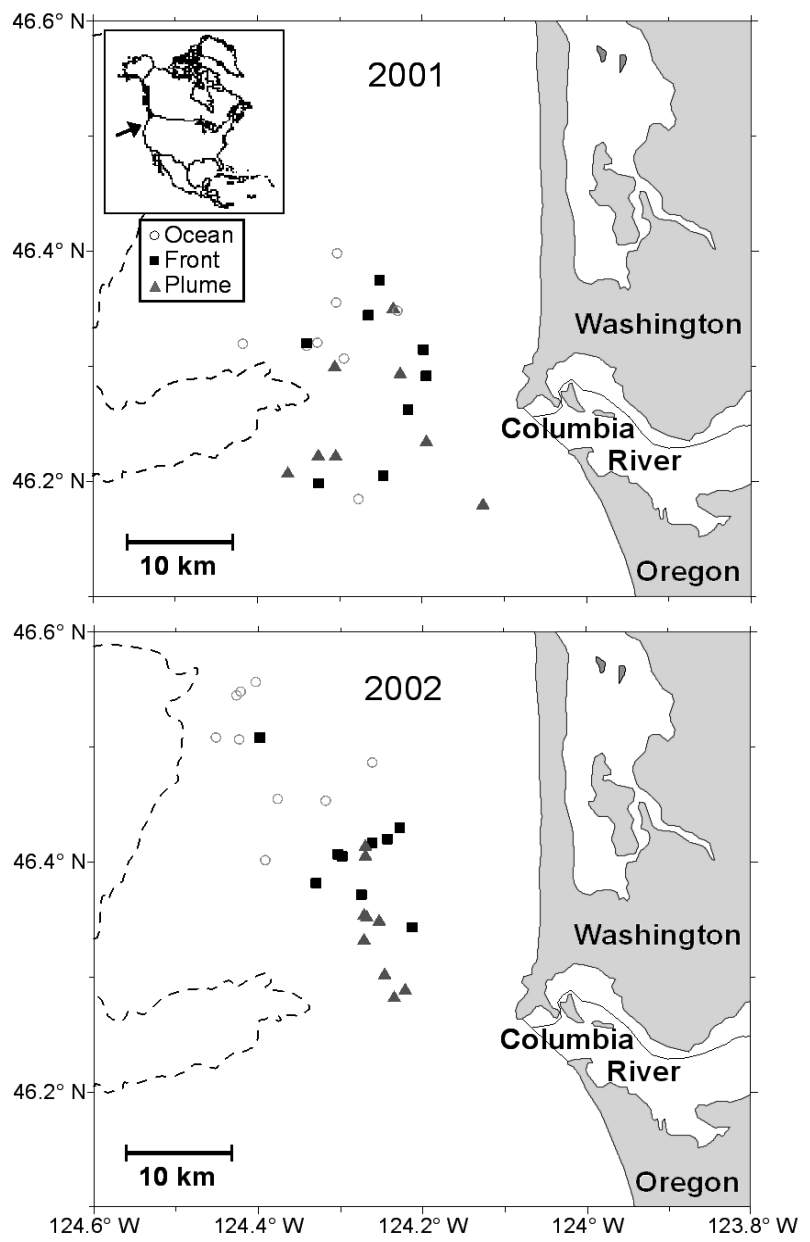

Fig. 3. Sampling locations off mouth of Columbia River in ocean, front and plume habitats in 2001 and 2002. Dashed line: $180 \mathrm{~m}$ depth contour (ocean) the front. To provide statistical control for spatial and temporal variability, the sampling was conducted in a blocked design, whereby each triplicate (sampling block) consisted of samples taken consecutively at ocean, front and plume stations.

Sampling stations were selected using a combination of visual observations and a flow-through CTD (conductivity, temperature, depth; Sea-Bird SBE19plus). Initially we attempted to randomize the order in which the ocean, front and plume habitats were sampled, but because we were unable to consistently locate the front in a reasonable amount of time, the front station was always sampled first. The surface expression of the front was clearly visible (Fig. 1), with distinct differences in water color and clarity, and often accompanied by accumulations of foam, flotsam and jetsam. Therefore, the front was located by visual observation, measurements of real-time flow-through surface salinities from the research vessel, and (in 2001) with the aid of an accompanying vessel (RV 'Sea Otter') and a US Coast Guard helicopter. The ocean and plume stations were then sampled in random order within a sampling block. These stations were selected by steaming perpendicularly away from the front until no large changes in surface salinity were observed.

The period from November 2000 to May 2001 was the second driest on record (1895 to 2002) in the Pacific Northwest compared to the 65th driest during the same period in 2001 and 2002 (see http://www.ncdc. noaa.gov). Consequently, snow melt and outflow from the Columbia River in May 2001 was almost half that in May 2002, whereas May 2002 outflow was close to the long-term average (Fig. 2). Because of the higher river flows in 2002, the ocean stations were located further from the river mouth and from the front (ocean-front distance: $2001, \bar{x}=7.8 \mathrm{~km} ; 2002, \bar{x}=13.0 \mathrm{~km})$ and plume (ocean-plume distance: $2001, \bar{x}=10.5 \mathrm{~km} ; 2002$, $\bar{X}=20.4 \mathrm{~km}$ ) in 2002 (Fig. 3). A total of 17 sampling blocks were completed, 8 in 2001, and 9 in 2002.

The physical characteristics of the water column at each station were measured with a CTD (Sea-Bird 19plus) profiler that was lowered to within $5 \mathrm{~m}$ of the bottom, or to a maximum of $100 \mathrm{~m}$. Water transparency was measured with a Secchi disc, and chlorophyll and nutrient samples were collected at $3 \mathrm{~m}$ depth using a Niskin bottle. Water samples were immediately filtered on pre-combusted Whatman ${ }^{\mathrm{TM}} \mathrm{GF} / \mathrm{F}$ filters and stored in centrifuge tubes for subsequent chlorophyll pigment analysis. The filtrate was saved for nutrient analysis and, along with the filters, kept frozen $\left(-20^{\circ} \mathrm{C}\right)$ in the dark until processed on shore. On shore, pigments were extracted in $90 \%$ HPLC grade acetone in deionized water for at least $12 \mathrm{~h}$ in a dark freezer before measuring sample fluorescence with a fluorometer (Turner Designs, 10-AU). Chlorophyll a was cal- 
culated from these fluorescence measurements. The concentration of phosphate $\left(\mathrm{PO}_{4}\right)$, silicate $\left(\mathrm{Si}[\mathrm{OH}]_{4}\right)$, nitrate $\left(\mathrm{NO}_{3}\right)$, nitrite $\left(\mathrm{NO}_{2}\right)$, and ammonium $\left(\mathrm{NH}_{4}\right)$ was determined in nutrient samples by the University of Washington (Seattle) Marine Chemistry Laboratory using standard methods adapted for an autoanalyzer (UNESCO 1994).

Water-column zooplankton were collected with a plankton net, and zooplankton in the upper $30 \mathrm{~cm}$ of the water column (neuston) were collected with a Manta neuston net (Brown \& Cheng 1981). The plankton net was either a $1 \mathrm{~m}$ diameter ring net (2001) or a $0.60 \mathrm{~m}$ bongo net (2002). Both were fitted with $335 \mu \mathrm{m}$ mesh and fished by letting out $60 \mathrm{~m}$ of cable and retrieving it immediately at $30 \mathrm{~m} \mathrm{~min}^{-1}$ while the vessel was underway at 2 knots. The angle of the wire was maintained so that this net fished to a maximum depth of 20 to $30 \mathrm{~m}$. The $0.97 \times 0.3 \mathrm{~m}, 335 \mu \mathrm{m}$ mesh neuston net was towed $60 \mathrm{~m}$ behind the vessel at the surface, but out of the wake, for 5 min while the vessel traveled at 2 knots. A calibrated flowmeter (General Oceanics) located inside the mouth of each net was used to estimate the amount of water filtered in each sample. Samples were immediately preserved in a $5 \%$ buffered formalin/seawater solution and returned to the laboratory for analysis.

Laboratory procedure. In the laboratory, plankton samples were rinsed, and all organisms over an average length of $2.5 \mathrm{~mm}$ counted. In addition to these larger organisms, all developmental stages of amphipods, barnacles, chaetognaths, crabs, cumaceans, euphausiids, fishes, isopods, mysiids, pteropods and shrimp were enumerated. These taxa were selected to correspond with known prey organisms of juvenile Chinook, coho, and chum salmon in this area (Brodeur 1989, 1991, Schabetsberger et al. 2003, De Robertis et al. 2005), and all are effectively retained by $335 \mu \mathrm{m}$ mesh. The entire sample was initially scanned for large rare organisms using a light table. Next, the sample was split using a Folsom splitter, and large, more common organisms were removed using a light table. Finally, a subsample of the split was taken using a Hensen stempel pipette (5 to $20 \mathrm{ml}$ ) to count smaller organisms. A dissecting microscope was used to identify all organisms to the lowest possible taxonomic level and developmental stage. After extrapolating catch sizes from subsample counts, the data were normalized using flowmeter data to produce density estimates of organisms $\mathrm{m}^{-3}$. Biomass of a given species was calculated by multiplying the number $\mathrm{m}^{-3}$ by the carbon weight of individuals of a given developmental stage. Estimates of zooplankton carbon content were derived from literature values (Strong \& Daborn 1979, Willams \& Robins 1979, Peterson 1980, Kafanov \& Fedotov 1982, Ross 1982a,b, Uye 1982, Sample et al. 1984, Vidal \& Smith 1986, Anger 1989, Ikeda \& Skjoldal 1989, Sum- mers 1993, Sulkin \& McKeen 1994, Ouellet et al. 1995) or from our own estimates of dry weight.

Data reduction and statistical methods. For all analyses, plankton were combined into the following groups: pteropods, large copepods, barnacle cyprid larvae, isopods, gammarid amphipods, hyperiid amphipods, euphausiid calyptopes, euphausiid furciliae, other decapods (crab zoea and shrimp larvae), Cancer magister (Dungeness crab) megalopae, other crab megalopae, insects, chaetognaths, Engraulis mordax (northern anchovy) eggs, Citharichthys spp. (unidentified sanddab spp.) eggs, and fish larvae.

We analyzed differences in plankton abundance, biomass, and physical features with respect to the plume, front, and ocean habitats using generalized linear models (McCullugh \& Nelder 1989). In all cases, we blocked the statistical analysis by habitat to reflect the experimental design, and set $\alpha$ to 0.05 .

For the physical data, we assumed a normal error structure based on examination of normal probability plots. The underlying data for the plankton samples were counts characterized by frequent zero counts. Thus we used count-based error structures for the plankton analysis. Although the counts were converted to densities based on volume of water sampled, count-based models were still appropriate because volume sampled represents exposure time to the underlying distribution (Lawless 1987). The 2 alternative models we considered were a Poisson model, which assumes that the mean is equal to the variance, and the negative binomial model, which is applicable to 'over-dispersed' data where the variance is larger than the mean (Welch \& Ishida 1993, Power \& Moser 1999). To chose between these 2 models, we performed an analysis of deviance (ANODEV) to determine whether the more complex negative binomial model was warranted.

If we found significant habitat effects in any of the independent variables, we performed multiple comparisons using Tukey's HSD test (Zar 1984) to determine how they varied among ocean, front, and plume habitats. The Tukey test compared habitats pairwise, taking into account block effects, to determine whether each pair was similar or different with respect to the independent variable tested. We used the S-Plus statistical software package (MathSoft 2000) for these analyses. For cases where there were too many zeros to run a parametric test, a Friedman test followed by Tukey tests was conducted to determine whether the independent variable tested differed between habitats.

A sequential multivariate statistical approach was used to determine if zooplankton community structure was consistently different among the 3 habitats. Plankton data were $\log (x+1)$-transformed for the multivariate analyses. Non-metric multidimensional scaling 
(NMDS) (Kruskal 1964, Mather 1976) was used to ordinate sample units (stations) in species space, to identify stations with similar zooplankton communities, and to relate zooplankton communities to environmental variables. Ordinations were conducted using PC-ORD Version 4.27 software (McCune \& Mefford 1999). The closer 2 stations are in species space, the closer the species composition of the stations (McCune \& Grace 2002). Runs were made using the Sørensen distance measure (Bray \& Curtis 1957). Plots and output of instability and stress were examined to find the number of ordination axes at which the reduction in stress gained by adding another axis was inconsequentially small (Mather 1976). Stress is a measure of the lack of fit of the ordination, represented by a few dimensions (axes), to the original station data in multidimensional species space; the lower the stress, the better the fit of the ordination. To minimize the chance of finding a local minimum in stress, Monte Carlo randomizations were run with 4 axes, 150 iterations, 10 runs of real data and 30 randomized runs. All ordinations were presented graphically with the dominant 2 axes for ease of visual interpretation. The orientations were rigidly rotated to maximize the correlation of the first axis with the environmental variable stability (the density gradient between $20 \mathrm{~m}$ and $\left.1 \mathrm{~m}\left[\Delta \sigma_{\mathrm{t}} / \Delta Z\right]\right)$ so that the ordinations were in a similar orientation and could be more easily compared.

The non-parametric blocked multi-response permutation procedure (MRPP) was used to test the null hypothesis of no difference in zooplankton community composition among habitats. This test is analogous to a randomized block ANOVA (McCune \& Grace 2002), but does not require distributional assumptions such as normality and homogeneity of variances. This test generates a p-value to evaluate the likelihood that an observed difference occurred by chance. Zooplankton samples were grouped by habitat and were then blocked by station for each net type and both years. The Euclidean distance measure was employed in all cases to allow for median alignment in blocked tests (which cannot be done with the Sørensen distance measure), and to maintain consistency among tests.

When MRPP revealed statistically significant differences in zooplankton community structure among habitats, indicator species analysis (ISA) (Dufrene \& Legendre 1997) was used to identify species groups that served as good indicators of the different habitats. The indicator value of a given species group is based on relative abundance of the species and frequency of occurrence of the species group in that habitat. The highest indicator value of each species is tested for statistical significance using a Monte Carlo randomization technique.

\section{RESULTS}

\section{Frontal features}

The plume formed a shallow (2 to $10 \mathrm{~m}$ ) lens of warmer, lower salinity water overlying the colder and more saline waters of the Oregon and Washington shelf (Fig. 4). The horizontal interface of the lowsalinity waters of the Columbia River plume and oceanic waters resulted in a highly visible surface front that was characterized by sharp color discontinuities and high surface energy (waves) and was often accompanied by foam and flotsam and aggregations of seabirds (Fig. 1c). The surface manifestation of the front was approximately 1 to $2 \mathrm{~m}$ wide. Fronts were extremely dynamic, forming shortly after higher high water and propagating out from the mouth of the Columbia River during ebb tide. The fronts were sufficiently visible to sample for 10 to $14 \mathrm{~h}$ after higher high tide, after which the reversal of the tides relaxed currents and the fronts dissipated.

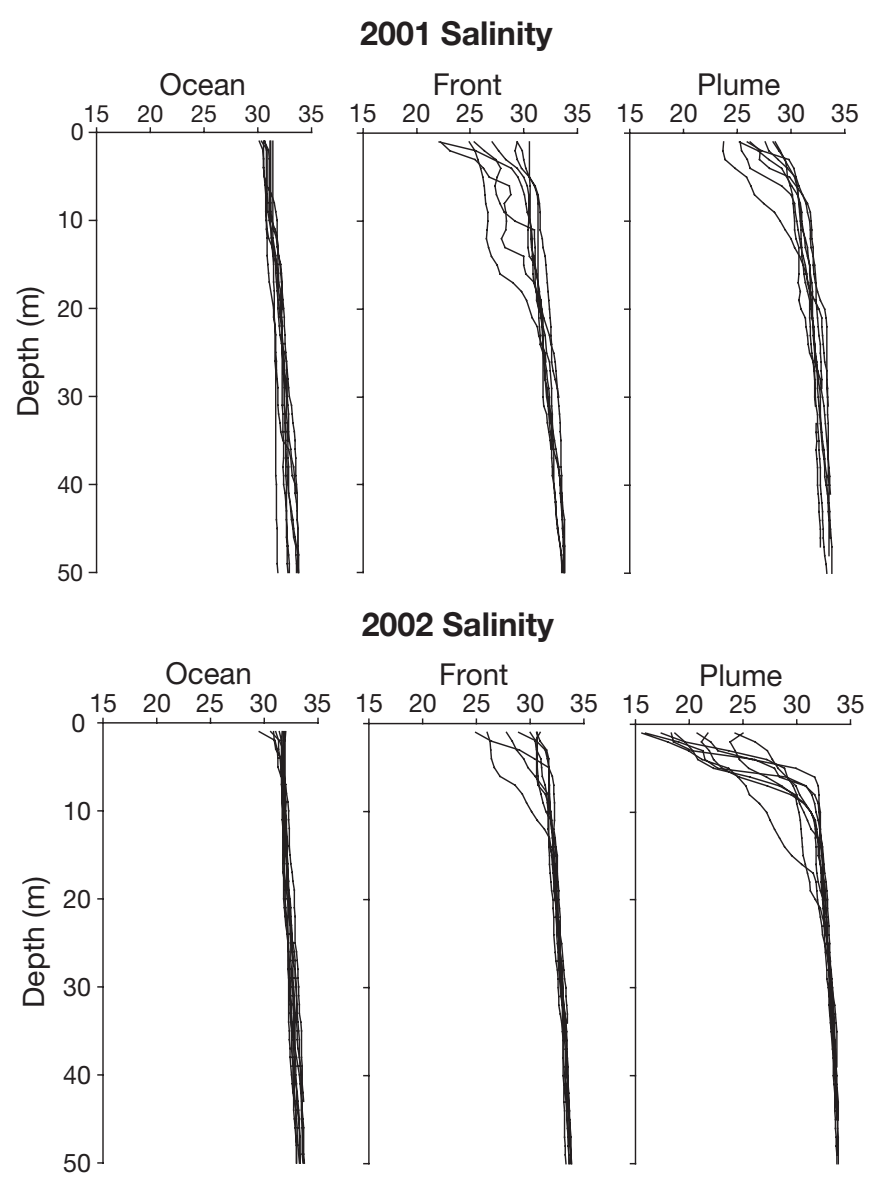

Fig. 4. Salinity profiles in ocean, front and plume habitats in 2001 and 2002 
Table 1. Generalized linear model analysis of physical and biological characteristics of ocean, front and plume habitats Shading demarcates significant differences between habitats identified by post-hoc tests. Values in each cell represent mean observation for that habitat. ${ }^{*} p<0.05 ;{ }^{* *} p<0.005$; $(\square)$ higher; ( $\square$ ) intermediate; ( $\square$ ) lower; $(\square)$ no difference

\begin{tabular}{|c|c|c|c|c|c|}
\hline \multirow{2}{*}{ Variable } & \multirow{2}{*}{ Year } & \multicolumn{4}{|c|}{ Habitat } \\
\hline & & Ocean & Front & Plume & $\mathrm{p}$ \\
\hline \multirow{2}{*}{ Station depth (m) } & 2001 & 89.8 & 78.4 & 75.2 & \\
\hline & 2002 & 91.1 & 66.7 & 58.0 & ${ }^{* *}$ \\
\hline \multirow{2}{*}{$\begin{array}{l}\text { Distance from N. Jetty } \\
(\mathrm{km})\end{array}$} & 2001 & 21.6 & 17.9 & 16.4 & $*$ \\
\hline & 2002 & 35.4 & 24.3 & 16.5 & *** \\
\hline \multirow{2}{*}{$\begin{array}{l}\text { Temperature at } 3 \mathrm{~m} \\
\text { depth }\left({ }^{\circ} \mathrm{C}\right)\end{array}$} & 2001 & 12.1 & 12.0 & 11.9 & \\
\hline & 2002 & 12.1 & 12.6 & 12.7 & $*$ \\
\hline \multirow{2}{*}{ Salinity at $3 \mathrm{~m}$ depth } & 2001 & 31.0 & 28.0 & 27.8 & ${ }^{* *}$ \\
\hline & 2002 & 31.6 & 30.0 & 22.4 & ${ }^{* *}$ \\
\hline \multirow{2}{*}{$\begin{array}{l}\text { Density at } 3 \mathrm{~m} \text { depth } \\
\left(\sigma_{\mathrm{t}}\right)\end{array}$} & 2001 & 23.4 & 21.2 & 21.0 & ${ }^{* *}$ \\
\hline & 2002 & 23.9 & 22.6 & 16.7 & ** \\
\hline \multirow{2}{*}{$\begin{array}{l}\text { Stability for } 20 \mathrm{~m} \text { to } \\
1 \mathrm{~m} \text { depth }\left(\Delta \sigma_{\mathrm{t}} / \Delta Z\right)\end{array}$} & 2001 & 0.1 & 0.2 & 0.3 & ** \\
\hline & 2002 & 0.1 & 0.2 & 0.5 & ** \\
\hline \multirow{2}{*}{$\begin{array}{l}\text { Chlorophyll } a \text { at } 3 \mathrm{~m} \\
\text { depth }\left(\mu g \mathrm{l}^{-1}\right)\end{array}$} & 2001 & 1.9 & 1.9 & 2.4 & \\
\hline & 2002 & 3.4 & 2.5 & 4.3 & \\
\hline \multirow{2}{*}{ Secchi depth (m) } & 2001 & 8.4 & 5.5 & 3.8 & ** \\
\hline & 2002 & 5.7 & 5.0 & 3.2 & ** \\
\hline \multirow{2}{*}{$\mathrm{PO}_{4}(\mu \mathrm{M})$} & 2001 & 0.2 & 0.3 & 0.4 & ** \\
\hline & 2002 & 0.1 & 0.1 & 0.2 & \\
\hline \multirow{2}{*}{$\mathrm{Si}(\mathrm{OH})_{4}(\mu \mathrm{M})$} & 2001 & 9.7 & 30.3 & 32.9 & ** \\
\hline & 2002 & 3.5 & 14.3 & 54.7 & $* *$ \\
\hline \multirow{2}{*}{$\mathrm{NO}_{3}(\mu \mathrm{M})$} & 2001 & 0.8 & 3.8 & 4.6 & $* *$ \\
\hline & 2002 & 0.1 & 0.4 & 3.3 & $* *$ \\
\hline \multirow{2}{*}{$\mathrm{NO}_{2}(\mu \mathrm{M})$} & 2001 & 0.1 & 0.1 & 0.2 & \\
\hline & 2002 & 0.05 & 0.04 & 0.08 & $* *$ \\
\hline \multirow{2}{*}{$\mathrm{NH}_{4}(\mu \mathrm{M})$} & 2001 & 0.3 & 0.9 & 0.9 & ${ }^{* *}$ \\
\hline & 2002 & 0.2 & 0.2 & 0.05 & ${ }^{*}$ \\
\hline
\end{tabular}

\section{Station depth and distance}

There was no significant difference in station depth (m) among habitats in 2001; however in 2002, the ocean stations were significantly deeper than the front and plume stations ( $p<0.005$, Table 1$)$. There was no significant difference in station depth for any habitat between years.

In both years the ocean station was significantly further from the mouth of the Columbia River (measured radially in $\mathrm{km}$ from the North Jetty) than the front and plume habitats ( $p<0.05$, Table 1$)$. In addition, both the ocean and front habitats were significantly further offshore in 2002 than in 2001 ( $p<0.05)$. This is consistent with more river outflow in 2002 than in 2001.

\section{Temperature, salinity and density}

The overall range in physical variables at $3 \mathrm{~m}$ depth for all stations sampled was greater in 2002 than in 2001. There was no significant difference in the mean temperature among habitats in 2001 (Table 1), but the plume was significantly warmer than the ocean and front habitats in 2002 ( $p<0.05)$. Both the front and plume habitats were significantly warmer in 2002 than in 2001 ( $p<0.005)$, but there was no significant difference in ocean habitat temperature between years.

In both years, mean salinity and density at $3 \mathrm{~m}$ depth were higher in the ocean habitat than the plume habitat, and were intermediate or equal between the front habitat and the plume (Table 1). The mean salinity of the front was more similar to that of the plume in 2001 and to the ocean habitat in 2002. Mean salinity of the plume at $3 \mathrm{~m}$ was 2.9 lower than in the ocean in 2001 and 9.2 lower than in the ocean in 2002 (Fig. 4). In 2001 the ocean habitat, and in 2002 both the ocean and front habitats, had significantly higher salinities than the plume habitats $(p<0.005)$. The ocean and front habitats were significantly more saline and dense in 2002 than in 2001 ( $p<0.05)$, while the plume habitat was significantly less saline and dense in 2002 than in 2001 ( $p<0.005)$. These measures were all consistent with higher river outflow in 2002 than in 2001.

Water-column stability was significantly higher in the plume than in the ocean habitat in both years (Table 1). Stability was also significantly higher at plume stations in 2002 than in 2001 ( $\mathrm{p}<0.001)$, indicating a greater degree of stratification in 2002.

\section{Pigments and nutrients}

There was no significant difference among the 3 habitats in mean chlorophyll a concentrations in either year (Table 1). Chlorophyll a concentrations in the plume were significantly higher in 2002 than in 2001 $(p<0.001)$, but were not significantly different between years in the ocean or front habitats.

All nutrients measured $\left(\mathrm{PO}_{4}, \mathrm{Si}[\mathrm{OH}]_{4}, \mathrm{NO}_{3}, \mathrm{NO}_{2}\right.$, $\mathrm{NH}_{4}$ ) were significantly ( $\mathrm{p}<0.05$, Table 1 ) higher in the plume than in the ocean, with the exception of $\mathrm{PO}_{4}$ in 2002 and $\mathrm{NO}_{2}$ in 2001. There were significant differences in nutrients between the 2 years in all habitats, with the exception of $\mathrm{NO}_{3}$ in the plume. In all cases, except for $\mathrm{Si}(\mathrm{OH})_{4}$ in the plume (significantly higher in 2002 than 2001, p < 0.05), all nutrients were significantly higher in all habitats in 2001 than in 2002 $(p<0.05)$. The average Bakun upwelling index (available at: www.pfeg.noaa.gov) indicated a period of mild upwelling (67) during our May 2001 sampling and a downwelling event (-28) during our May 2002 study. 


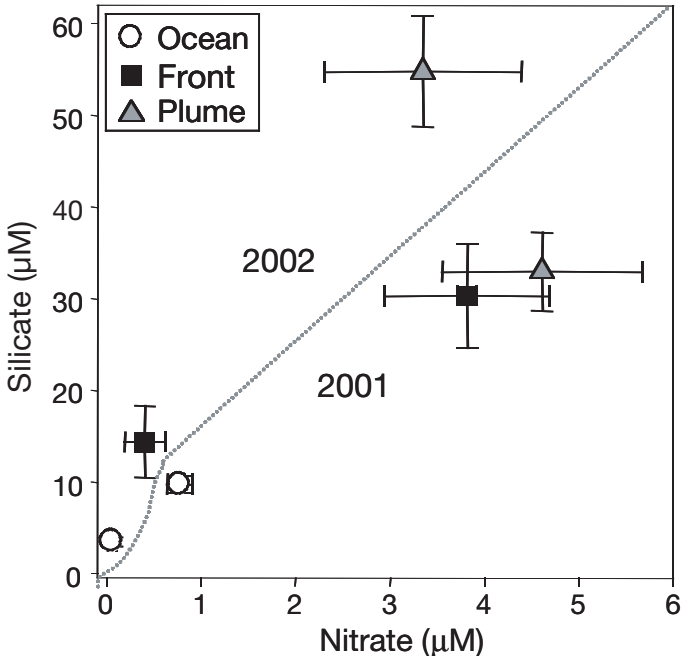

Fig. 5. Mean $( \pm 1 \mathrm{SE})$ nitrate versus silicate in ocean, front and plume habitats in 2001 and 2002

Silicate and nitrate have been used as measures of the relative influence of the Columbia River plume and upwelling (Hill \& Wheeler 2002). Silicate is known to be high in the Columbia River plume, and in both years average silicate concentration was significantly higher in the plume than in the ocean habitats, whereas the front habitat was intermediate (Table 1,

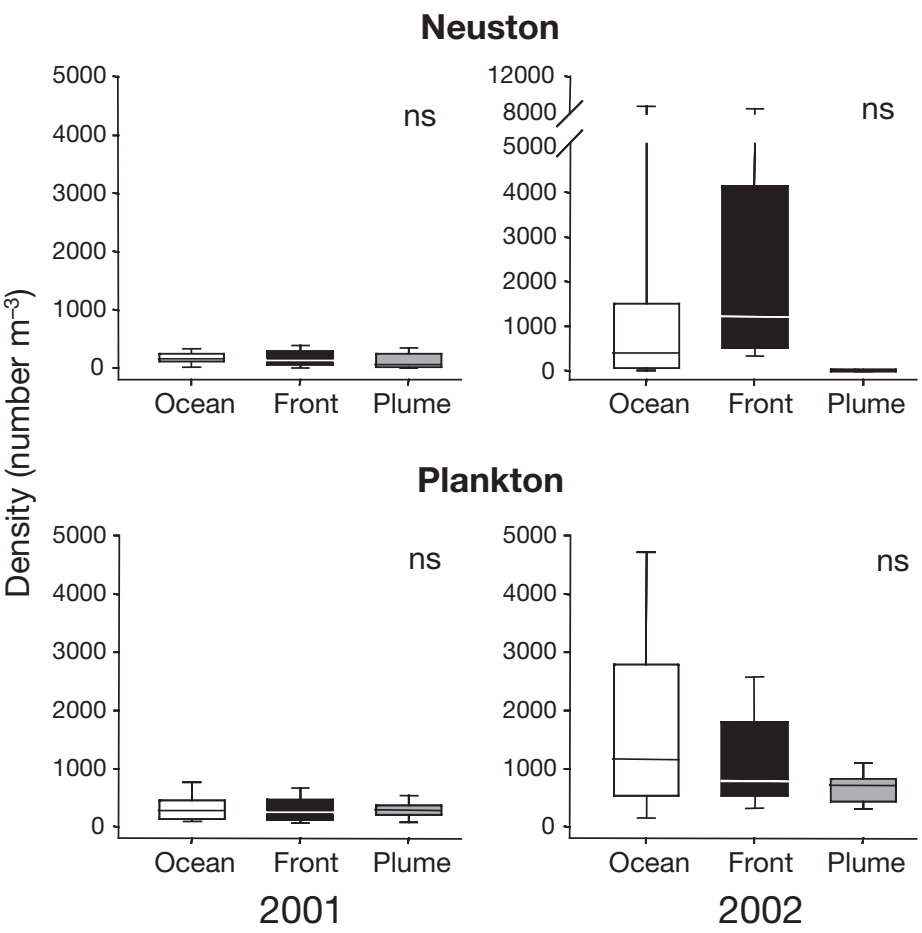

Fig. 6. Density of enumerated taxa in ocean, front and plume habitats in neuston and plankton. Box plots demarcate 10th, 25th, 50th, 75th and 90th percentiles. ns: no significant difference among habitats
Fig. 5). Silicate was higher in the plume in 2002, the year with higher river outflow. Nitrate was relatively low in all habitats in both years, but showed the same trend as silicate, with higher concentrations in the plume than in the ocean habitat, while the front habitat was intermediate. Nutrient characteristics of the front habitat resembled more the plume habitat in 2001, and more the ocean habitat in 2002 (Table 1, Fig. 5).

\section{Plankton and neuston density and biomass}

The total density of taxa examined was not significantly higher in either the plankton or neuston nets for the front habitat versus the ocean or plume in either 2001 or 2002 (Fig. 6). Total densities were higher in the front habitat in 6 of the 17 station blocks in the plankton net, and in 9 of 17 station blocks in the neuston net. Higher plankton densities in the ocean or plume habitats were often attributable to the presence of euphausiid calyptopis larvae (Thysanoessa spinifera or Euphausia pacifica), which were often extremely abundant, especially in the ocean habitat (Table 2).

Although collectively the total density of enumerated taxa was not higher in the frontal habitat, many individual taxa were significantly more abundant in frontal than in plume and oceanic waters (Table 2).

These taxa, some of which are important prey of juvenile salmonids (De Robertis et al. 2005), were Cancer magister megalopae, insects, Citharichthys spp. and Engraulis mordax eggs, gammarid amphipods, barnacle cyprid larvae, copepods, and fish larvae. In addition, taxa which were more abundant in the frontal habitat were also more abundant in the upper $0.3 \mathrm{~m}$ (neuston) versus the upper 20 to $30 \mathrm{~m}$ sampled by the plankton nets (Table 2).

The total biomass of zooplankton was significantly higher in the front than in the ocean or plume habitats for plankton net samples in 2002 and for neuston net samples in both years ( $p<0.005$, Fig. 7). Total zooplankton biomass was higher in the front habitat for 11 of 17 station blocks in the plankton net, and for all 17 station blocks in the neuston net. The average zooplankton biomass in the front habitat was 4 times higher than in the other habitats (average of ocean and plume habitats) in the 2001 neuston and 2002 plankton samples and 47 times higher in the 2002 neuston. Taxa that were more abundant in the neuston compared to the plankton were much more likely to be concentrated at fronts (Fig. 8, Spearman's rank correlation: $2001, R_{\mathrm{S}}=0.83, \mathrm{p}<0.001 ; 2002, R_{\mathrm{S}}=0.79, \mathrm{p}<$ $0.001)$. The majority of higher biomass in the 
Table 2. Generalized linear model analysis of density (number $1000 \mathrm{~m}^{-3}$ ) of taxa in neuston, meter (2001) and bongo (2002) nets in ocean, front and plume habitats; data presented as in Table 1. When there were too many zeros to run a parametric test, a Friedman test was conducted, where ${ }^{*} \wedge$ indicates Friedman $\mathrm{p}<0.05$; tz: too many zero values for statistical analysis; ns: not significant.

$(\square)$ higher; ( $\square$ ) lower; $(\square)$ no difference

\begin{tabular}{|c|c|c|c|c|c|c|c|c|c|}
\hline \multirow{2}{*}{ Taxon } & \multirow{2}{*}{ Year } & \multicolumn{4}{|c|}{ Neuston } & \multicolumn{4}{|c|}{ Meter/Bongo } \\
\hline & & Ocean & Front & Plume & $\mathrm{p}$ & Ocean & Front & Plume & $\mathrm{p}$ \\
\hline \multirow{2}{*}{ Cancer magister megalopae } & 2001 & 60 & 2509 & 233 & ${ }^{* *}$ & 3 & 381 & 16 & ** \\
\hline & 2002 & 67 & 84718 & 2325 & $* *$ & 5 & 879 & 68 & $*$ \\
\hline \multirow{2}{*}{ Insects } & 2001 & 10 & 101 & 18 & $* *$ & 0 & 52 & 0 & $* \wedge$ \\
\hline & 2002 & 4 & 193 & 9 & $* *$ & 0 & 17 & 0 & $* \wedge$ \\
\hline \multirow{2}{*}{ Citharichthys spp. eggs } & 2001 & 25699 & 21303 & 3261 & ${ }^{*}$ & 23437 & 13001 & 4547 & * \\
\hline & 2002 & 40487 & 255154 & 76 & $* *$ & 7557 & 37215 & 7935 & $* *$ \\
\hline \multirow{2}{*}{ Engraulis mordax eggs } & 2001 & 70215 & 65811 & 19464 & ns & 77310 & 30705 & 17943 & $* *$ \\
\hline & 2002 & 42855 & 2485768 & 3562 & $* *$ & 13188 & 633542 & 87703 & $* *$ \\
\hline \multirow{2}{*}{ Gammarid amphipods } & 2001 & 238 & 268 & 3 & ns & 8 & 39 & 9 & * \\
\hline & 2002 & 19 & 484 & 2 & ${ }^{* *}$ & 0 & 70 & 10 & ${ }^{*}$ \\
\hline \multirow{2}{*}{ Barnacle cyprid } & 2001 & 4 & 105 & 33 & $*$ & 0 & 57 & 0 & $* \wedge$ \\
\hline & 2002 & 397 & 6926 & 38 & ${ }^{* *}$ & 29 & 821 & 5 & $* *$ \\
\hline \multirow{2}{*}{ Copepods } & 2001 & 5316 & 31136 & 13761 & $*$ & 18279 & 50133 & 13161 & ns \\
\hline & 2002 & 3312 & 20273 & 30 & $* *$ & 16372 & 8974 & 2840 & ns \\
\hline \multirow{2}{*}{ Isopods } & 2001 & 0 & 14 & 7 & ns & 0 & 2 & 0 & $* \wedge$ \\
\hline & 2002 & 0 & 35 & 1 & ${ }^{* *}$ & 0 & 0 & 0 & $\mathrm{tz}$ \\
\hline \multirow{2}{*}{ Fishes } & 2001 & 88 & 6 & 319 & ns & 5 & 5 & 25 & ns \\
\hline & 2002 & 7 & 53 & 3 & ${ }^{* *}$ & 45 & 69 & 29 & ns \\
\hline \multirow{2}{*}{ Crab megalopae } & 2001 & 0 & 1 & 6 & ns & 3 & 4 & 14 & ns \\
\hline & 2002 & 42 & 3004 & 117 & * & 101 & 715 & 54 & ${ }^{*}$ \\
\hline \multirow{2}{*}{ Hyperiid amphipods } & 2001 & 11 & 14 & 9 & ns & 39 & 48 & 72 & ns \\
\hline & 2002 & 77 & 0 & 0.3 & ${ }^{* *}$ & 241 & 128 & 77 & ${ }^{*}$ \\
\hline \multirow{2}{*}{ Decapods } & 2001 & 2 & 0 & 1201 & ${ }^{* *}$ & 571 & 1158 & 10015 & ** \\
\hline & 2002 & 11546 & 3285 & 19 & $*$ & 4481 & 1865 & 1931 & ns \\
\hline \multirow{2}{*}{ Euphausiid calyptopes } & 2001 & 66200 & 51898 & 74822 & ns & 214695 & 196884 & 211382 & ns \\
\hline & 2002 & 1819307 & 14014 & 4618 & ns & 1575520 & 439437 & 516344 & $*$ \\
\hline \multirow{2}{*}{ Euphausiid furciliae } & 2001 & 1239 & 4030 & 3206 & ns & 4606 & 5558 & 11942 & ns \\
\hline & 2002 & 20344 & 16338 & 211 & ns & 88040 & 32664 & 50684 & ns \\
\hline \multirow{2}{*}{ Pteropods } & 2001 & 0 & 559 & 1265 & ns & 552 & 1927 & 1541 & ns \\
\hline & 2002 & 0 & 1 & 6 & $\mathrm{tz}$ & 2112 & 4340 & 3368 & ns \\
\hline \multirow{2}{*}{ Chaetognaths } & 2001 & 3309 & 1089 & 7435 & ${ }^{*}$ & 5045 & 3878 & 16568 & $*$ \\
\hline & 2002 & 12 & 17 & 0 & ns & 1190 & 381 & 1004 & $\mathrm{~ns}$ \\
\hline
\end{tabular}

vicinity of fronts can be attributed to Cancer magister megalopae, which are relatively large, and buoyant fish eggs (Citharichthys spp. and Engraulis mordax), which were extremely abundant (Table 2).

\section{Community analysis}

Non-metric multidimensional scaling (NMDS) revealed differences in the community structure among habitats. The stress values for these ordinations were between 8 and 15\%, which is in the 'good-to-fair' criterion range (McCune \& Grace 2002). NMDS ordinations revealed that the zooplankton community composition was different among habitats for the neuston, but much less so for the plankton (Fig. 9). Differences in zooplankton community structure as a function of habitat were observed in both years in the neuston. However, in 2002 (Fig. 9b) the zooplankton community composition was much more distinct among habitats (less overlap) than in 2001 (Fig. 9a). MRPP analysis indicated that plankton and neuston community com- 


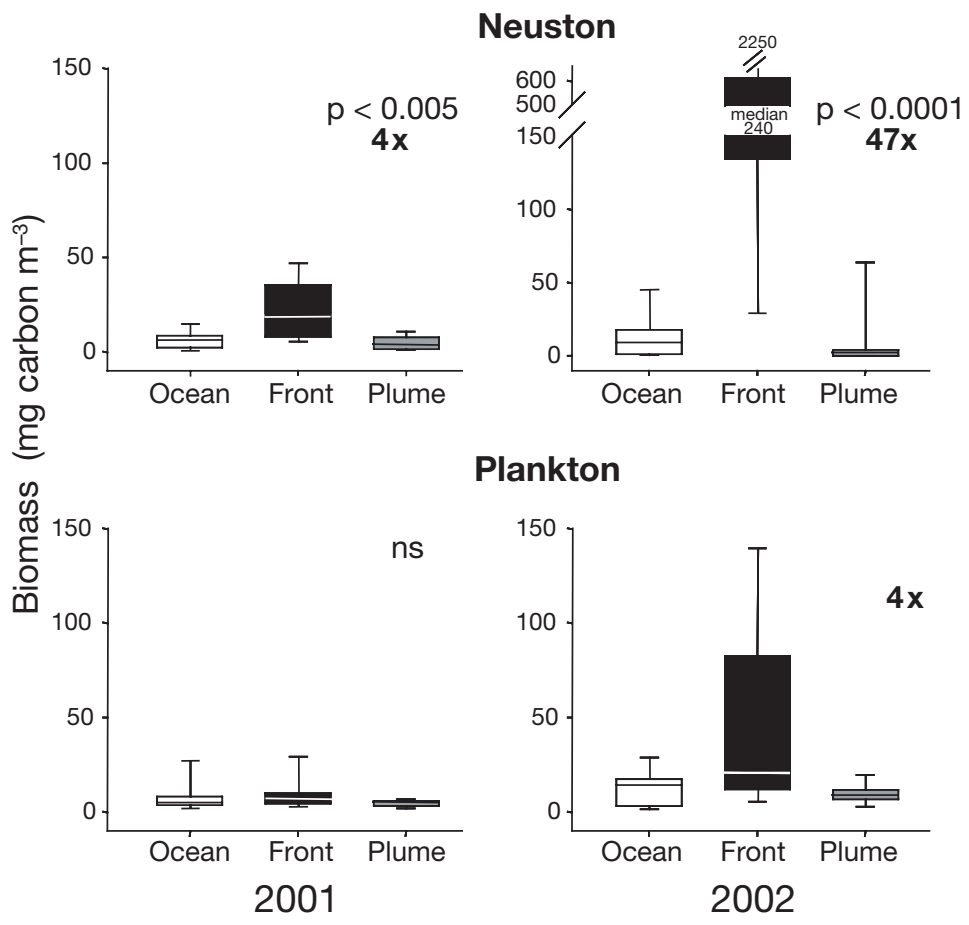

Fig. 7. Biomass of enumerated taxa in ocean, front and plume habitats in neuston and plankton. Box plots as in Fig. 6. Values in bold: amount by which average biomass in the front habitat exceeds that in ocean and plume habitats. ns: no significant difference among habitats

position was significantly different among habitats for both years $(\mathrm{p}<0.05)$.

Indicator species analysis (ISA) also supported the conclusions of the generalized linear model analyses
(GLM). In $87.5 \%$ of cases, the same species were associated with the same habitat using both methods, so although the statistical results were slightly different, the results were consistent; therefore, complete results of the ISA will not be presented here. In only 8 of 64 cases did the ISA results differ from the GLM. The additional species that ISA added as indicators of certain habitats were consistent with the trends observed in the GLM analyses, although the results were not statistically significant (Table 2). The consistency between these 2 different methods gives us confidence in the identified differences in plankton abundance among the ocean, front and plume habitats.

\section{DISCUSSION}

Our study revealed that the well-defined fronts that form at the leading edge of the Columbia River plume result in a strong demarcation of plankton communities. This was due largely to the concentration of surface-oriented species along the front, particularly Dungeness crab megalopae Cancer magister and the buoyant eggs of northern anchovy and sanddab (Engraulis mordax and Citharichthys spp.). The existence of large numbers of insects, dominated by live lady bugs (family Coccinellidae) in the front suggests that the formation of the front may be a relatively rapid phenomenon.
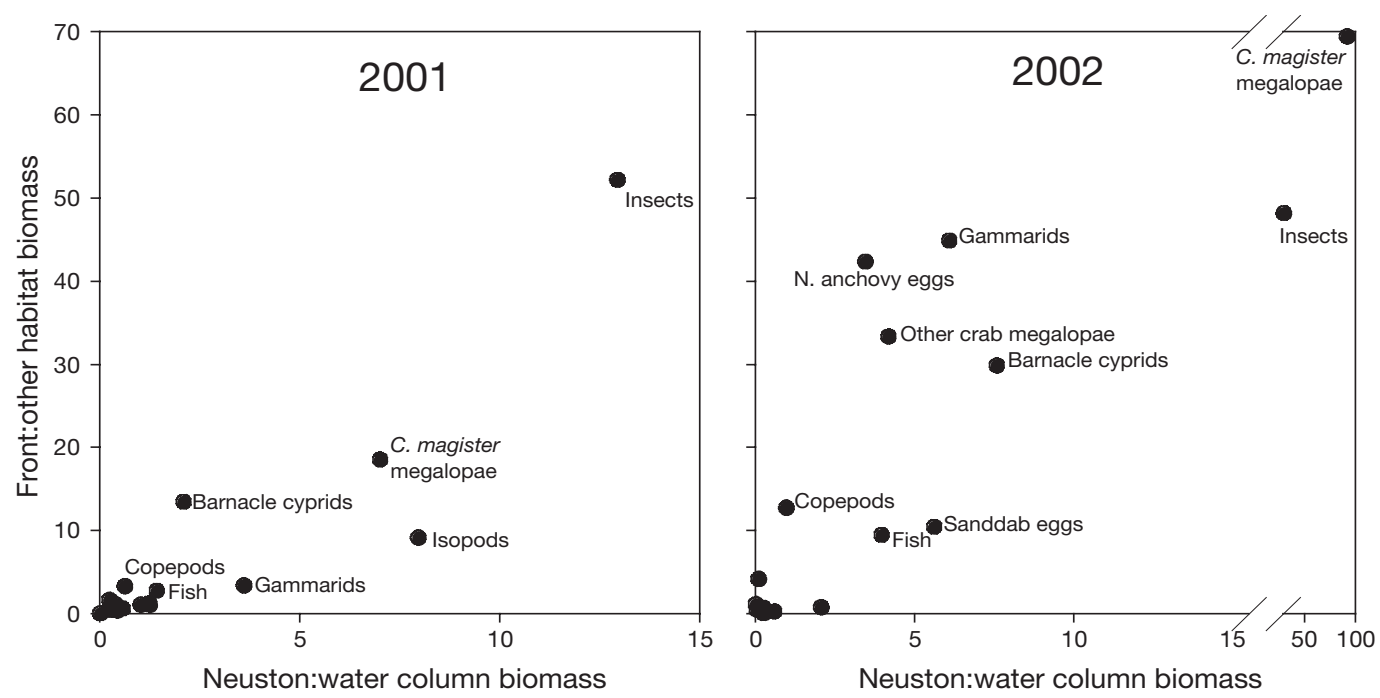

Fig. 8. Taxon-specific comparison of relative abundance in neuston and the degree of concentration in frontal areas, showing ratio of average neuston biomass (all habitats combined) to water column (plankton) biomass (all habitats combined) versus ratio of average biomass of both neuston and water column in front habitat to average in plume and ocean habitat in 2001 and 2002. Positive correlation between these 2 ratios indicates that taxa that are distributed primarily in near-surface waters are disproportionately concentrated at fronts 


\section{Neuston}

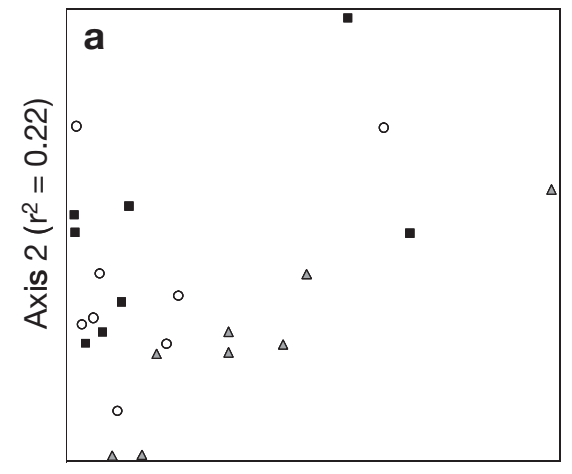

Axis $1\left(r^{2}=0.62\right)$

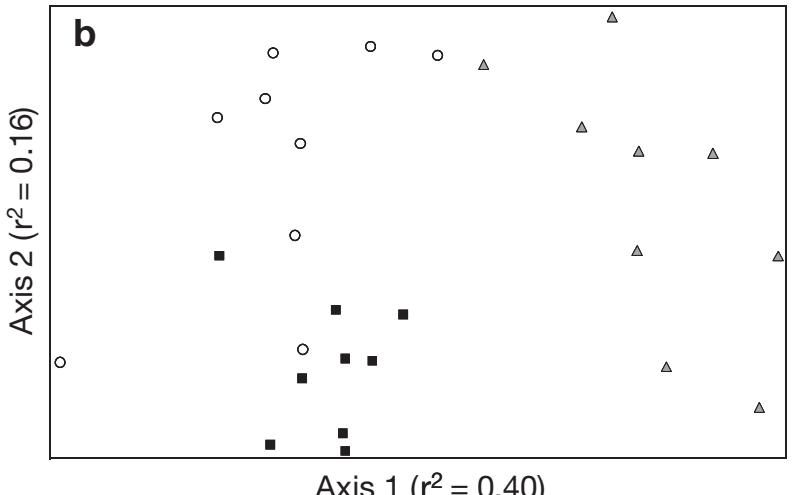

Axis $1\left(r^{2}=0.40\right)$

1-Meter/Bongo

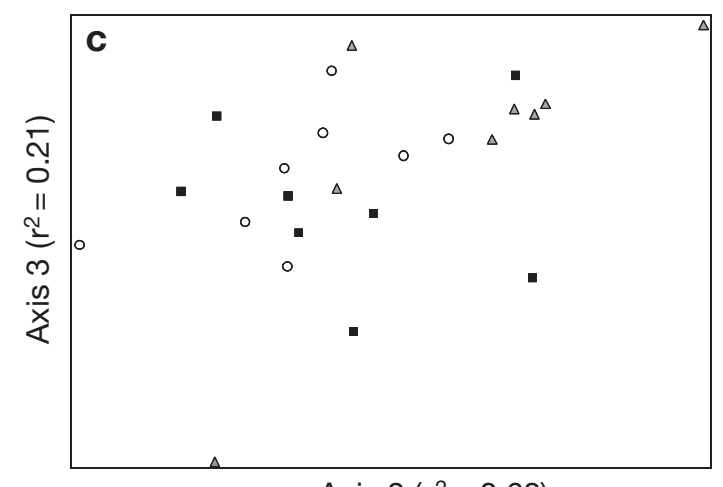

Axis $2\left(r^{2}=0.68\right)$

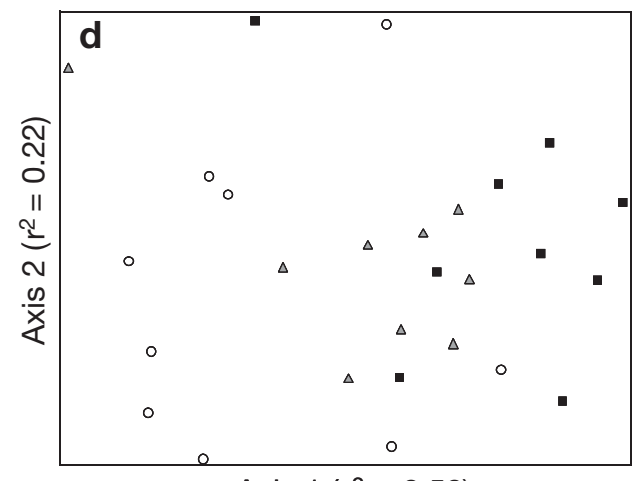

Axis $1\left(r^{2}=0.50\right)$

Fig. 9. Non-metric multidimensional scaling ordination of (a) 2001 neuston net, (b) 2002 neuston net, (c) 2001 plankton (1 m) net, and (d) 2002 plankton (bongo) net. Each data point represents a sampled station, whereby clustered points indicate more similar community structure. $\mathrm{r}^{2}$ : percentage of variance explained along each axis; total of the 2 axes = percentage of original variance explained by 2-dimensional representation of ordination shown

The ocean, front and plume habitats were physically distinct, with large contrasts between the lower-salinity plume, which was shallow and highly stratified, and the higher-salinity ocean habitat. The frontal habitats were ephemeral, but recurrent on a tidal cycle, and were also visually distinct, demonstrating marked differences in water color and clarity, accumulation of foam and flotsam, high-energy waves and increased bird activity. Despite the fact that fronts were shortlived, the differences were consistent and they did demarcate very distinct physical conditions (i.e. habitats). Pigments and nutrients were not significantly higher in the fronts than in the ocean or plume habitat. Therefore, it is not likely that these fronts are regions of higher production, which is not surprising given the ephemeral nature of the frontal habitats.

Increased zooplankton biomass in the frontal zones is a result of physical convergence concentrating surface-oriented organisms, rather than changes in birth or mortality rates leading to higher production. Al- though we did not measure convergence rates or zooplankton demography, the fronts persisted for timescales (hours) that are much shorter than the generation times of the zooplankton (on the order of months) and the observed increases in biomass at fronts are thus attributable to concentration rather than population growth. Density of all zooplankton combined was not higher at the fronts, but density and biomass of surface-oriented zooplankton taxa were elevated in frontal zones. This explains the differences in zooplankton community structure: if all zooplankton were concentrated at fronts at the same rate, then the abundance of zooplankton would be consistently higher at fronts compared to ocean and plume habitats, but community structure would remain the same.

Total zooplankton biomass was elevated at fronts compared to adjacent ocean and plume habitats, and densities and biomass of surface-oriented taxa were 4 to 47 times higher at fronts and in the neuston than in the adjacent ocean and plume waters. Taxa that were 
more abundant in the neuston versus in the water column (plankton) were also more abundant in the front compared to the ocean and plume habitats (Fig. 8). This differential distribution of taxa among habitats led to the differences observed in zooplankton community structure among the ocean, front and plume habitats. Differences in the front habitat zooplankton community structure can primarily be attributed to the increased concentration of surface-oriented taxa. These differences at the front were even more pronounced in the neuston, which lends further support to the hypothesis that these organisms are concentrated due to near-surface convergence. These findings of higher concentrations at fronts of neustonic organisms are consistent with Franks' (1992) model prediction, and from first principles that organisms maintaining near-surface distributions, either through active swimming behavior or buoyancy, will become concentrated by convergent flows at fronts.

We also observed a difference between years, with higher river outflow and downwelling conditions in 2002, versus low river outflow and upwelling conditions in 2001. Differences in the total zooplankton density and biomass among habitats were more pronounced in 2002 than in 2001. Biomass at fronts was higher than at ocean and plume habitats in 2002 in both the neuston and the plankton. The differences in zooplankton community structure were also more pronounced in 2002 than in 2001. The distances among the habitats were much greater in the community analysis in 2002, especially in the neuston. One might hypothesize that the differences seen in zooplankton distribution were partially a result of these differences in the physical environment. Although we found substantial differences in community composition and overall biomass between the 2 years, it is difficult to ascribe these differences to any particular factor with just 2 yr of data. However this does suggest strong inter-annual variability in both physical and biological conditions in the Columbia River plume and front, and this could have implications for fish populations that utilize these areas.

In the García Berdeal et al. (2002) model of the Columbia River plume, when ambient ocean currents are southward and winds are southerly and downwelling-favorable, the plume is advected toward the shore and slightly to the north. Under these conditions, a higher density gradient at the edge of the plume is seen; this was also reported by Fong \& Geyer (2001). If a higher gradient were coupled with high river outflows, such as those present during 2002, this could translate into greater convergence at the plume margins. In contrast, when ambient ocean currents are southward and there are upwelling-favorable winds (from the north), the model predicts that the plume is more spread out offshore, and progresses southward from a location straight off the river mouth. Under these conditions the model predicts a lower density gradient at the plume edge. If this lower gradient were coupled with lower river outflows, such as those during 2001, one might expect less convergent flow toward the plume margin. The model predictions of higher convergence associated with conditions like those experienced during May 2002 are consistent with our findings of a higher concentration of surface-oriented taxa in 2002 than in 2001.

The taxa that were concentrated at fronts during this study are all organisms that juvenile salmon have been found to consume (Brodeur 1989, 1991, Schabetsberger et al. 2003, De Robertis et al. 2005). Juvenile salmon are often surface-oriented feeders (Brodeur 1989), and given that many Columbia River basin salmon enter the ocean when river flow is high and frontal formation is intensified, there is a potential for salmon to take advantage of high prey density at frontal features. However, as reported in De Robertis et al. (2005), while there is some indication of frontand plume-related influence on the distribution of juvenile salmonids, there is no indication that juvenile salmonids are found consistently in higher densities at fronts and no evidence that juvenile salmon are primarily consuming taxa that are disproportionately concentrated at the fronts. Although, as demonstrated by our analysis of plankton communities, potential prey taxa were consistently elevated at fronts in both years of the study, it is likely that the transience of these features prevents the juvenile salmonids from fully utilizing this resource (De Robertis et al. 2005).

While the potential of a recurrent, rich food resource in frontal habitats exists, juvenile salmonids do not seem to be utilizing fronts as feeding grounds; however it could be that smaller planktivorous fishes benefit from localized prey aggregation. For example, northern anchovy spawn in the Columbia River plume region, and their buoyant eggs are concentrated in fronts. When the larvae hatch, they too may be accumulated at the fronts, and the higher zooplankton biomass in these habitats may provide them with concentrated prey resources at a critical time in their life history.

In summary, we found that zooplankton and larval fishes, which were surface-oriented either through active behavior or passive buoyancy, were concentrated at convergent fronts at the leading edge of the Columbia River plume. This in turn led to differences in zooplankton community structure and composition among the ocean, front and plume habitats. These local changes in the abundance and composition of planktonic communities have the potential to result in large changes in the amount and type of prey available to pelagic predators. 
Acknowledgements. We thank the captain and crew of the FV 'Frosti', R. Brodeur, C. Bucher, E. Casillas, R. Emmett, and R. Schabetsberger for their excellent assistance and good humor at sea. P. Orton and D. Jay were helpful in the discussion of plume dynamics. We are grateful to M. Parnel for identification of the larval fishes, and P. Bentley for chlorophyll analysis. We especially thank S. Hinton for her around-theclock logistical support and aerial photographs, and the US Coast Guard of Group Astoria for helicopter overflights. The comments of R. Brodeur, E. Casillas, R. Emmett, W. T. Peterson, and J. Zamon improved the manuscript. This work and C.A.M. were supported by a grant from the Bonneville Power Administration to the National Marine Fisheries Service and from NMFS to Oregon State University. A.D.R. was supported by a National Research Council Postdoctoral Fellowship. Reference to trade names does not imply endorsement by the National Marine Fisheries Service, NOAA.

\section{LITERATURE CITED}

Anger K (1989) Growth and exuvial loss during larval and early juvenile development of the hermit crab Pagurus bernhardus reared in the laboratory. Mar Biol 103: 503-511

Bowman MJ (1988) Estuarine fronts. In: Kjerfve B (ed) Hydrodynamics of estuaries. CRC Press, Boca Raton, FL, p 85-132

Bowman MJ, Iverson RL (1978) Estuarine and plume fronts: proceedings of a workshop held at the Marine Sciences Research Center. In: Esaias WE (ed) Oceanic fronts in coastal processes. Springer-Verlag, Berlin, p 87-104

Bray JR, Curtis JT (1957) An ordination of the upland forest communities in southern Wisconsin. Ecol Monogr 27: 325-349

Brodeur RD (1989) Neustonic feeding by juvenile salmonids in coastal waters of the Northeast Pacific. Can J Zool 67: 1995-2007

Brodeur RD (1991) Ontogenetic variations in the type and size of prey consumed by juvenile coho, Oncorhynchus kisutch, and chinook, O. tshawytscha, salmon. Environ Biol Fish 30:303-315

Brown DM, Cheng L (1981) New net for sampling the ocean surface. Mar Ecol Prog Ser 5:225-227

Chiba S, Ishimaru T, Hosie GW, Fukuchi M (2001) Spatiotemporal variability of zooplankton community structure off east Antarctica (90 to $160^{\circ}$ E). Mar Ecol Prog Ser 216: 95-108

De Robertis A, Morgan CA, Schabetsberger RA, Zabel RW and 5 others (2005) Columbia River plume fronts. II. Distribution, abundance, and feeding ecology of juvenile salmon. Mar Ecol Prog Ser 299:33-44

Dufrene M, Legendre P (1997) Species assemblages and indicator species: the need for a flexible asymmetrical approach. Ecol Monogr 67:345-366

Eggleston DB, Armstrong DA, Elis WE, Patton WS (1998) Estuarine fronts as conduits for larval transport: hydrodynamics and spatial distribution of Dungeness crab postlarvae. Mar Ecol Prog Ser 164:73-82

Epifanio CE (1987) The role of tidal fronts in maintaining patches of brachyuran zoeae in estuarine waters. J Crustac Biol 7:513-517

Fong DA, Geyer WR (2001) Response of a river plume during an upwelling favorable event. J Geophys Res C 106: $1067-1084$

Franks PJS (1992) Sink or swim: accumulation of biomass at fronts. Mar Ecol Prog Ser 82:1-12

García Berdeal I, Hickey BM, Kawase M (2002) Influence of wind stress and ambient flow on a high discharge river plume. J Geophys Res C 107:3130

Garvine RW, Monk JD (1974) Frontal structure of a river plume. J Geophys Res 79:2251-2259

Govoni JJ, Grimes CB (1992) The surface accumulation of larval fishes by hydrodynamic convergence within the Mississippi River plume front. Cont Shelf Res 12:1265-1276

Grimes CB, Finucane JH (1991) Spatial distribution and abundance of larval and juvenile fish, chlorophyll and macrozooplankton around the Mississippi River discharge plume, and the role of the plume in fish recruitment. Mar Ecol Prog Ser 75:109-119

Hickey BM, Banas NS (2003) Oceanography of the US Pacific northwest coastal ocean and estuaries with application to coastal ecology. Estuaries 26:1010-1031

Hill JK, Wheeler PA (2002) Organic carbon and nitrogen in the northern California current system: comparison of offshore, river plume, and coastally upwelled waters. Prog Oceanogr 52:369-387

Ikeda T, Skjoldal HR (1989) Metabolism and elemental composition of zooplankton from the Barents Sea during early Arctic summer. Mar Biol 100:173-183

Kafanov AI, Fedotov PA (1982) Relation between body length and weight in some amphipods of the littoral of the Vityaz' Bay (Sea of Japan). Sov J Mar Biol 8:190-196

Kruskal JB (1964) Nonmetric multidimensional scaling: a numerical method. Psychometrika 29:115-129

Lawless JF (1987) Negative binomial and mixed Poisson regression. Can J Stat 15:209-225

Le Févre J (1986) Aspects of the biology of frontal systems. Adv Mar Biol 23:163-299

MacGregor JM, Houde ED (1996) Onshore-offshore pattern and variability in distribution and abundance of bay anchovy Anchoa mitchilli eggs and larvae in Chesapeake Bay. Mar Ecol Prog Ser 138:15-25

Mackas DL, Louttit GC (1988) Aggregation of the copepod Neocalanus plumchrus at the margin of the Fraser River plume in the Strait of Georgia. Bull Mar Sci 43:810-824

Mather PM (1976) Computational methods of multivariate analysis in physical geography. John Wiley \& Sons, London

MathSoft (2000) S-plus 6.0 guide to statistics. Data Analysis Division, MathSoft, Seattle, WA

McCullugh P, Nelder JA (1989) Generalized linear models. Chapman \& Hall, London

McCune B, Grace JB (2002) Analysis of ecological communities. MJM Software Design, Gleneden Beach, OR

McCune B, Mefford MJ (1999) Multivariate analysis of ecological data. Version 4.27. MJM Software Design, Gleneden Beach, OR

Munk P, Hansen BW, Nielsen TG, Thomsen HA (2003) Changes in plankton and fish larvae communities across hydrographic fronts off West Greenland. J Plankton Res 25:815-830

Olson DB, Hitchcock GL, Mariano AJ, Ashjian CJ, Peng G, Nero RW, Podestá GP (1994) Life on the edge: marine life and fronts. Oceanography 7:52-60

Ouellet P, Taggart CT, Frank KT (1995) Early growth, lipid composition, and survival expectations of shrimp Pandalus borealis larvae in the northern Gulf of St. Lawrence. Mar Ecol Prog Ser 126:163-175

Pearcy WG, Keene DF (1974) Remote sensing of water color and sea surface temperatures off the Oregon coast. Limnol Oceanogr 19:573-583

Peterson WT (1980) Life history and ecology of Calanus marshallae in the Oregon upwelling zone. PhD thesis, Oregon State University, Corvallis, OR 
Power JH, Moser EB (1999) Linear model analysis of net catch data using the negative binomial distribution. Can J Fish Aquat Sci 56:191-200

Ross RM (1982a) Energetics of Euphausia pacifica. I. Effects of body carbon and nitrogen and temperature on measured and predicted production. Mar Biol 68:1-13

Ross RM (1982b) Energetics of Euphausia pacifica. II. Complete carbon and nitrogen budgets at $8^{\circ}$ and $12^{\circ} \mathrm{C}$ throughout the life span. Mar Biol 68:15-23

Russell RW, Harrison NM, Hunt GL (1999) Foraging at a front: hydrography, zooplankton, and avian planktivory in the northern Bering Sea. Mar Ecol Prog Ser 182:77-93

Sample BE, Cooper RJ, Greer RD, Whitmore RC (1984) Estimation of insect biomass by length and weight. Am Midl Nat 129:234-240

Schabetsberger R, Morgan CA, Brodeur RD, Potts CL, Peterson WT, Emmett RL (2003) Prey selectivity and diel feeding chronology of juvenile chinook (Oncorhynchus tshawytscha) and coho (O. kisutch) salmon in the Columbia River plume. Fish Oceanogr 12:523-540

Shanks AL, Wright WG (1987) Internal-wave-mediated shoreward transport of cyprids, megalopae, and gammarids and correlated longshore differences in the settling rate of intertidal barnacles. J Exp Mar Biol Ecol 114: $1-13$

Shanks AL, Largier J, Brink L, Brubaker J, Hooff R (2000) Demonstration of the onshore transport of larval invertebrates by the shoreward movement of an upwelling front. Limnol Oceanogr 45:230-236

Shanks AL, Largier J, Brink L, Brubaker J, Hooff R (2002) Observations on the distribution of meroplankton during a downwelling event and associated intrusion of the Chesapeake Bay estuarine plume. J Plankton Res 24: 391-416

Shanks AL, McCulloch A, Miller J (2003) Topographically generated fronts, very nearshore oceanography and the

Editorial responsibility: Otto Kinne (Editor-in-Chief), Oldendorf/Luhe, Germany distribution of larval invertebrates and holoplankters. J Plankton Res 25:1251-1277

Strong KW, Daborn GR (1979) Growth and energy utilisation of the intertidal isopod Idotea baltica (Pallas) (Crustacea: Isopoda). J Exp Mar Biol Ecol 41:101-123

Sulkin SD, McKeen G (1994) Influence of temperature on larval development of four co-occurring species of the brachyuran genus Cancer. Mar Biol 118:593-600

Summers PL (1993) Life history, growth and aging in Thysanoessa spinifera. MSc thesis, University of Victoria, BC

UNESCO (1994) Protocols for the Joint Global Ocean Flux Study (JGOFS) core measurements. IOC Intergovernment Oceanographic Commission, UNESCO, Paris. Manuals and guides. Rep 29

Uye SI (1982) Length-weight relationships of important zooplankton from the inland Sea of Japan. J Oceanogr Soc Jpn 38:149-158

Uye SI, Yamaoka T, Fujisawa T (1992) Are tidal fronts good recruitment areas for herbivorous copepods? Fish Oceanogr 1:216-226

Vidal J, Smith SL (1986) Biomass, growth, and development of populations of herbivorous zooplankton in the southeastern Bering Sea during spring. Deep-Sea Res 33:523-556

Welch DW, Ishida Y (1993) On the statistical distribution of salmon in the sea: application of the negative binomial distribution, and the influence of sampling effort. Can J Fish Aquat Sci 50:1029-1038

Willams R, Robins D (1979) Caloric, ash, carbon and nitrogen content in relation to length and dry weight of Parathemisto gaudichaudi (Amphipoda: Hyperiidea) in the north east Atlantic Ocean. Mar Biol 52:247-252

Zar JH (1984) Biostatistical analyses, 2nd edn. Prentice-Hall, Englewood Cliffs, NJ

Zeldis JR, Jillett JB (1982) Aggregation of pelagic Munida gregaria (Fabricius) (Decapoda, Anomura) by coastal fronts and internal waves. J Plankton Res 4:839-857

Submitted: September 28, 2004; Accepted: April 7, 2005 Proofs received from author(s): August 16, 2005 